\title{
International Investment Activity in the Context of the Foreign Relations of Ukraine with Countries of the European Union
}

\author{
OLEKSII KULAKOV ${ }^{1}$, IRINA BABIY ${ }^{2}$, ANATOLII HAVRYLIAK ${ }^{3}$, MYKHAILO BILOKON ${ }^{4}$, \\ OLENA DIKAN ${ }^{5}$, TETYANA MIROSHICHENKO ${ }^{6}$ \\ ${ }^{1}$ Kramatorsk, UKRAINE, E-mail: oleksiikulakov7@gmail.com \\ ${ }^{2}$ KHMELNYTSKYI NATIONAL UNIVERSITY, UKRAINE, E-mail: irbabiy115@gmail.com \\ ${ }^{3}$ NATIONAL UNIVERSITY LVIV POLYTECHNIC, UKRAINE, Email: anatolii.s.havryliak@Ipnu.ua \\ ${ }^{4}$ KHARKIV REGIONAL INSTITUTE OF PUBLIC ADMINISTRATION OF THE NATIONAL ACADEMY OF PUBLIC \\ ADMINISTRATION UNDER THE PRESIDENT OF UKRAINE, UKRAINE, E-mail: michael.belokon@gmail.com \\ ${ }^{5}$ UKRAINIAN STATE UNIVERSITY OF RAILWAY TRANSPORT, UKRAINE, E-mail: a.dikan2018@ukr.net \\ ${ }^{6}$ V. N. KARAZIN KHARKIV NATIONAL UNIVERSITY, UKRAINE, E-mail: tatiana.miroschnichenko@karazin.ua
}

\begin{abstract}
The necessary regulation of international investment activity can be carried out using economic, administrative and legal methods, as well as tools of motivation and restraint was shown in the article. The domestic strategy in the field of foreign relations is not limited to creating favorable conditions for investment activity, but also includes an active role of the state government in shaping the system of long-term investment in the economy was researched. The benefits of public investment programs were considered. The main methods of risk assessment of international investment activity in the sphere of foreign relations of Ukraine were defined. Based on an analysis of the investment volume of projects of different directions over a five-year period, the tendency to increase investments was identified. The model for assessing the impact of EU foreign investment projects on the economy has been developed.
\end{abstract}

Keywords: International investment activity; Foreign relations; External relations; International economics; Regulation.

JEL Classification: F30, E44, M31 


\title{
La Actividad Inversora Internacional en el Contexto de las Relaciones Exteriores de Ucrania con los Países de la Unión Europea
}

\author{
OLEKSII KULAKOV ${ }^{1}$, IRINA BABIY², ANATOLII HAVRYLIAK ${ }^{3}$, MYKHAILO BILOKON ${ }^{4}$, \\ OLENA DIKAN ${ }^{5}$, TETYANA MIROSHICHENKO ${ }^{6}$ \\ ${ }^{1}$ Kramatorsk, UKRAINE, E-mail: oleksiikulakov7@gmail.com \\ ${ }^{2}$ KHMELNYTSKYI NATIONAL UNIVERSITY, UKRAINE, E-mail: irbabiy115@gmail.com \\ ${ }^{3}$ NATIONAL UNIVERSITY LVIV POLYTECHNIC, UKRAINE, Email: anatolii.s.havryliak@lpnu.ua \\ ${ }^{4}$ KHARKIV REGIONAL INSTITUTE OF PUBLIC ADMINISTRATION OF THE NATIONAL ACADEMY OF PUBLIC \\ ADMINISTRATION UNDER THE PRESIDENT OF UKRAINE, UKRAINE, E-mail: michael.belokon@gmail.com \\ ${ }^{5}$ UKRAINIAN STATE UNIVERSITY OF RAILWAY TRANSPORT, UKRAINE, E-mail: a.dikan2018@ukr.net \\ ${ }^{6}$ V. N. KARAZIN KHARKIV NATIONAL UNIVERSITY, UKRAINE, E-mail: tatiana.miroschnichenko@karazin.ua
}

\begin{abstract}
RESUMEN
La necesaria regulación de la actividad inversora internacional puede llevarse a cabo utilizando métodos económicos, administrativos y legales, así como herramientas de motivación y restricción fue mostrada en el artículo. La estrategia nacional en el ámbito de las relaciones exteriores no se limita a la creación de condiciones favorables para la actividad de inversión, sino que también incluye un papel activo del gobierno estatal en la configuración del sistema de inversión a largo plazo en la economía fue investigado. Se consideraron los beneficios de los programas de inversión pública. Se definieron los principales métodos de evaluación del riesgo de la actividad inversora internacional en el ámbito de las relaciones exteriores de Ucrania. Sobre la base de un análisis del volumen de inversión de proyectos de diferentes direcciones durante un período de cinco años, se identificó la tendencia a aumentar las inversiones. Se ha desarrollado el modelo de evaluación del impacto de los proyectos de inversión extranjera de la UE en la economía.
\end{abstract}

Palabras claves: Actividad inversora internacional; Relaciones exteriores; Economía internacional; Regulación.

Clasificación JEL: F30, E44, M31 


\section{Introduction}

At the present stage of economic development of Ukraine, it is important that the direction of the state's investment policy is directed towards achieving a favorable domestic investment climate in Ukraine and further stimulating the attraction of foreign investments into the Ukrainian economy. As a result, foreign investments should become the major part of Ukraine's internal economic development processes. Foreign investments from different countries of the EU (hereinafter - the EU) are coming into the economy of Ukraine through regional development programs with the support of the EU. These EU programs help to develop Ukraine's economy, namely to improve the economic environment, to develop public authorities, to improve the humanitarian situation, to modernize infrastructure, to implement energy-saving measures, to increase the role of civil society in implementing democratic reforms, to strengthen the personal and public safety, support small and medium-sized businesses etc. It is necessary to make changes in the economy of Ukraine in order for international investments to provide a favorable economic environment, as a result, which will lead to increase profits in the country's economy and improve the quality of life of the population (Kolesnik et al., 2019). However, investing in the Ukrainian economy is fraught with various risks that may affect investment performance, which necessitates the resolution of problems related to the risks involved in international investment activity. And it is necessary to solve the problems of international investment in the economy of Ukraine for the development of all sectors of the domestic economy and increase the competitiveness of products (Syverson, 2019). Also, the development of international investment is necessary for the scientific and technological development of Ukraine, since such a direction of development is essential for the most developed countries of the world.

\section{Literature review}

The publications of foreign economists are devoted to the problems of international investment activity. R. Desbordes in his writings explores the foreign direct investment and productivity: a crosscountry, multisector analysis (Desbordes, Franssen, 2019). C. Syverson elaborates in his articles the investments in macroeconomics and market power: context, implications, and open questions (Syverson, 2019). D. Duke considers in his works the Green impact investing in emerging markets: rethinking Green impact investing in emerging markets (Duke, 2017). L. Barrow develops in her research the financial incentives and educational investment: the impact of performance-based scholarships on student time use (Barrow, 2018). M. Fabus researches impact of foreign direct investment on unemployment development in selected regions of Slovak Republic (Fabus, 2015). R. Greenwood explores waves in ship prices and investment (Greenwood, Hanson, 2015). P. K. Naik considers interaction of institutional investment activity and stock market volatility: evidence from India (Naik, Padhi, 2015). C. M. Mason elaborates Business Angel Investment Activity in the financial crisis: UK evidence and policy implications (Mason, Harrison, 2015). L. Casi researches foreign direct investment and growth: posibilities different regional identities shape the returns to foreign capital investments (Casi, Resmini, 2017; Koniaieva, and Babenko, 2019). N. Bhasin explores Bilateral investment treaties promote foreign direct investments (FDI) inflows (Bhasin, Manocha, 2016).

Noting the significant contribution of foreign scientists, it should be noted that international investment activity has not been fully explored in the context of Ukraine's external relations with the EU (memon et al 2018).

The purpose of the article is to analyze international investment activity in Ukraine through cooperation with EU countries (Babenko et al., 2019), to study the stimulation of the processes of international investment activity development based on regulation of this activity to realize the active role of the government of the state in investing (Písař, 2019), forming state investment programs and assessing the risks of international investment activity. 


\section{Data and methodology}

International investment activity plays a major role in the system of foreign relations and has a great impact on the economy of the country, so this activity need to be regulated at the domestic and international levels. The necessary regulation of international investment activity can be carried out using economic, administrative and legal methods, as well as tools of motivation and limitation.

Legal methods are implemented through a system of regulatory acts. At the same time, administrative methods control property issues. In turn, economic methods are implemented through a system of investments, loans, grants and more.

Regulation methods have a close relationship. All methods are spelled out in certain regulatory acts (Palyvoda et al., 2018). The effectiveness of the methods depends on the perfection and quality of the legal acts (Kaminskyi et al., 2020).

Formation of regulatory methods is carried out in two ways: the first way is implemented through the adoption of a legislative framework at the domestic level that regulates international investment activity in the country's economy; the second way is implemented through the adoption of regulatory acts that regulate all aspects of international investment activity at the regional level (Matsongoni, Mutambara, 2018).

The domestic strategy in the field of foreign relations shows that international investment activity is not limited to creating favorable conditions for investment activity (Klimuk, Kochurko, 2018), but also includes an active role of the state government in shaping the system of long-term investments in the economy (Nepryadkina, 2019).

In the EU, countries carry out international investment activity through indirect government intervention in the development of the economy, this need is due to the fact that many of the investment tasks in countries require such intervention (Mason, and Harrison, 2015).

State regulation of investments in the economy in the countries of the EU is carried out through many development programs and investments are distributed across different sectors of the economy, which is why different types of special state investment institutes work.

\section{Results}

The main mechanisms for regulating investments in the economy by state, on an example of the countries of the EU should be:

1. Controll (aiding or constraint) the amount of investments is the basic mechanism for managing the investment process through borrowing programs, as well as tax, monetary and trade programs.

2. Motivation of investing in certain spheres of economy and enterprises through tax and credit privileges.

3. Impact through intervention in the administration of the investment process to coordinate the plans and actions of enterprises.

The state should give priority to investments that have great benefits, namely:

- investing goes into entrepreneurship, ensuring the implementation of the latest achievements of science, advanced technologies, know-how, etc.;

- investments have a positive impact on taxation in the country;

- investments stimulate the integration of the domestic economy into the world economy through scientific, trade and industrial cooperation, facilitating the rise of economic and business activities.

The main methods of risk assessment of international investment activity in the field of foreign relations include:

1. Economic-mathematical method, which gives the opportunity to obtain the most reasonable from the economic-mathematical standpoint risk characterization. 
2. Expert method that is implemented if there is not enough data to develop the calculations by economic-mathematical method and allows to make a complex estimation for several components.

3. An empirical method based on investing experience, that is, provides an opportunity to determine the level of risk, using both own and borrowed investment experience.

It is recommended to apply risk assessment methods of international investment activity together and make a positive decision, provided that all methods are positively assessed.

In today's international economy, to assess the risks of international investment activity it is necessary to take the following actions: to analyze the factors that influence the risks; identify risks; assess the risks.

At the stage of analyzing the factors that influence the risk of international investment activity, it is necessary to identify the main influential factors, among which the most common are: growth of gross domestic product, unemployment rate, inflation rate, the situation in the country, etc.

At the stage of risk identification of international investment activity it is proposed to identify and analyze the risks. To realize the risk identification, the information base, which is formed by collecting and processing the collected information, is essential. At this stage, the risk analysis should start with identifying the sources and causes that indicate the events that may cause the risk.

At the stage of risk assessment of international investment activity, direct risk assessment is carried out by economic-mathematical, expert and empirical methods.

If, as a result of the assessment, the level of risk is in line with the norm, then it is necessary to proceed to the investment stage. If, as a result of the assessment, the level of risk significantly exceeds the norm, then the risk should be minimized, or if the risk cannot be minimized, then the investment decision should be postponed until more favorable investment conditions occur.

The basis of international investment activity is a set of projects implemented on the basis of plans of public authorities in Ukraine, international organizations and diplomatic missions to achieve economically and socially important goals. EU foreign investment contributes to improving the socioeconomic level of the country's development through the introduction of various high-tech technologies, job creation by small and medium-sized enterprises, modernization of enterprise equipment, which leads to the adaptation of domestic enterprises to EU standards, etc.

The level of investment from EU countries to Ukraine in different years was analyzed. The results of the analysis of the level of investment from EU countries to Ukraine in different years are presented in Figure 1.

Figure 1 The level of investment from EU countries in different years on the example of Donetsk region (UAH)

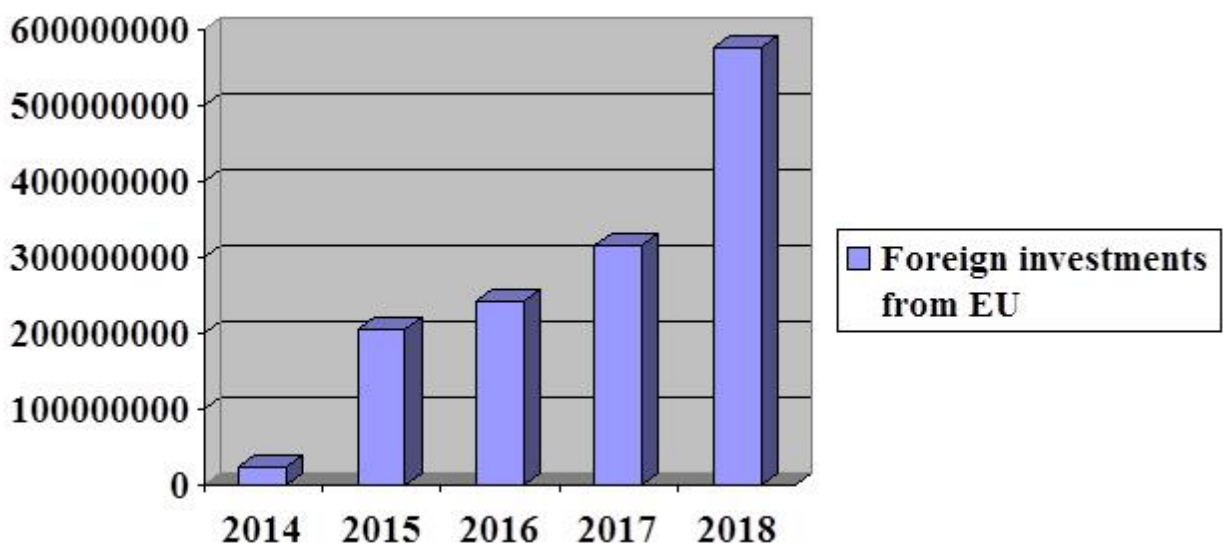


As can be seen from Figure 1, the volume of investment of various projects tends to increase over five years. This indicates the good implementation of the plans of state authorities in Ukraine, international organizations and diplomatic missions to increase investments in the Donetsk region. It is imperative that this trend be maintained and improved in order to implement EU norms and to inform the public in the field of European integration.

\section{Experimental}

To determine the impact of investment on the economic environment, it is necessary to build a model for assessing the impact of EU foreign investment projects on the economy. To build a model for assessing the impact of EU foreign investment projects on the economy, the amount of foreign investments per hryvnia of gross regional product on the example of Donetsk region was calculated. The calculations take into account the reports of the department of of investment innovative development and foreign relations of Donetsk regional state administration on the projects of international technical assistance of the EU, which have been implemented for 5 years (Donetsk regional state administration, 2020).

The model for assessing the impact of EU foreign investment projects on the economy:

where:

$$
\mathrm{I}_{\mathrm{C} .}=\frac{\mathrm{A}_{\mathrm{i}}}{\mathrm{V}_{\mathrm{GRP}}}
$$

IC. - investments of EU international technical assistance projects implemented over 5 years (ratio of investments of EU international technical assistance projects to the volume of gross regional product), \%;

$\mathrm{Al}$ - volume of investments of EU international technical assistance projects implemented over 5 years, UAH;

VGRP - volume of gross regional product, UAH.

This model will allow to determine the impact of foreign investment in the economy. As the volume of foreign investments is important for the development of the economy of Ukraine and its regions.

The results of calculations of the model of assessment of the impact of EU foreign investment projects on the regional economy are shown in Figure 2, which reveals the level of impact of EU foreign investment projects on the regional economy.

Figure 2 Results of calculations of the model of impact of EU foreign investment projects on the economy of the region (percentages)

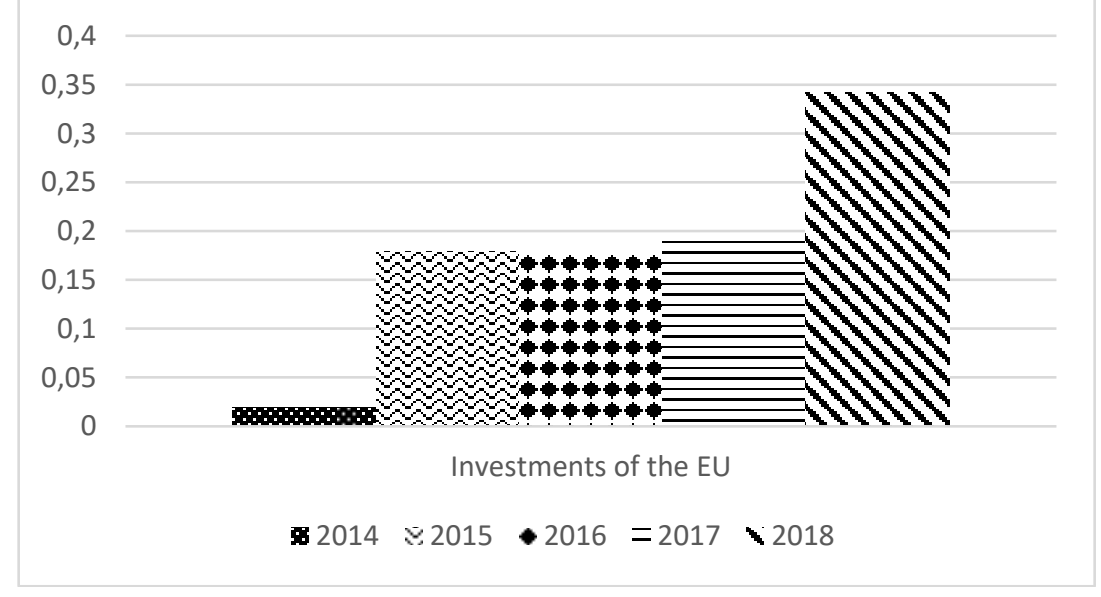

As can be seen from Figure 2, there is an increase of the impact of EU foreign investments on the development of the Donetsk region, which has a major impact on the development of the region's economy and living standards. Development indicators of Donetsk region may be increased, given the trend. Improvement of Donetsk region's indicators is possible due to the development of foreign 
relations with the EU, primarily due to the development of interregional and international cooperation. More formal activities involving international organizations and the diplomatic missions are needed, as well as conclude international treaties.

\section{Conclusion}

International investment activity in Ukraine through cooperation with EU countries, to study the stimulation of the processes of international investment activity development based on regulation of this activity to realize the active role of the government of the state in investing, forming state investment programs and assessing the risks of international investment activity are analyzed.

On the basis of the processes of regulation of international investment activity, the article investigates the stimulation of the processes of development of this activity in order to realize the active role of the government of the state in forming the system of long-term investments in the economy.

Using the analysis of scientific works of domestic and foreign scientists, it is revealed that it is necessary to regulate international investment activity by means of economic, administrative and legal methods, as well as instruments of motivation and limitation for influencing the economy of the country.

The analysis of the experience of the European Union countries shows that the main mechanisms that provide for government regulation of investing in the economy are control (assistance or restriction), motivation and influence to create the greatest benefits from investing.

Based on the analysis of scientific works, the benefits that are gained from investing in the introduction of the latest scientific achievements, identifying the positive impact on taxation in the country and identifying the possibilities of integration of the domestic economy into the world economy are determined.

The basic methods of risk assessment of international investment activity in the sphere of foreign relations are defined. In the analysis of scientific works the basic methods and actions in the process of risk assessment of international investment activity are offered.

The conducted research shows the importance of the main direction of development of Ukraine and its regions due to attracting investments from EU countries, since EU countries are the largest investors for the development of Ukraine for efficient development of investment activity of Ukraine.

Based on an analysis of the investment volume of projects of different directions over a five-year period, the tendency to increase investments in the territory of Donetsk region was identified in order to determine the possibility of improving these indicators for the implementation of EU norms, as well as informing the public in the field of European integration.

The model for assessing the impact of EU foreign investment projects on the economy has been developed by calculating the ratio of investments in EU technical assistance projects and the volume of gross regional product, which will allow to determine the impact of foreign investments in the economy.

Taking into account the results of calculations of the model of assessment of the impact of EU foreign investment projects on the economy, the level of impact of EU foreign investment projects on the economy of the region was shown to identify the possibility of improvement of indicators due to the development of interregional and international cooperation.

\section{Acknowledgements}

Thanks, Doctor of science (Economics), Professor, Donetsk national technical university Olha Popova, which provided help during the research, namely proof reading the article. 


\section{References}

1. Babenko, V., Sidorov, V., Koniaieva, Y., Kysliuk, L., 2019. "Features in scientific and technical cooperation in the field of non-conventional renewable energy." Global Journal of Environmental Science and Management, 5 (SI), 105-112. http://dx.doi.org/10.22034/gjesm.2019.05.SI.12

2. Barrow, L., Rouse, C. E., 2017. "Financial incentives and educational investment: the impact of performance-based scholarships on student time use." SSCR Electronic Journal, 11(3-4):112-125.

3. Bhasin, N., and Manocha, R., 2017. "Do Bilateral Investment Treaties Promote FDI Inflows? Evidence from India. Vikalpa:" The Journal for Decision Makers, 41(4):275-287.

4. Casi, L., and Resmini, L., 2017. "Foreign direct investment and growth: Can different regional identities shape the returns to foreign capital investments?" Environment and Planning C: Politics and Space, 35(8):1483-1508.

5. Department of investment innovative development and foreign relations of Donetsk regional state administration, 2020. Donetsk regional state administration. Retriewed from: www.dn.gov.ua on March 3, 2020.

6. Desbordes, R., and Franssen, L., 2019. "Foreign Direct Investment and Productivity: A CrossCountry, Multisector Analysis". Asian Development Review, 36(1):54-79.

7. Duke, D., and Simanis, E., 2017. "From Home Runs to Base HitsRethinking Green Impact Investing in Emerging Markets: Rethinking Green Impact Investing in Emerging Markets." Innovations: Technology, Governance, Globalization, 11(3-4):112-125.

8. Fabus, M., 2015. "Impact of foreign direct investment on unemployment development in selected regions of Slovak Republic." Economic Annals-XXI, 155(11-12):63-66.

9. Gaponova, E., Babenko, V., Nehrey, M., Ryzhikova, N., Zaporozhets, E., 2019. "Life Expectancy of Population of the Country: the Role of Health Services Effectiveness". Research in World Economy, 10(4) (Special Issue), 86-91. https://doi.org/10.5430/rwe.v10n4p86

10.Greenwood, R., and Hanson, S. G., 2015. "Waves in Ship Prices and Investment." The Quarterly Journal of Economics, 130(1):55-109.

11.Herrison Matsongoni and Emmanuel Mutambara, 2018. "An assessment of informal SMEs' potential in an African economy - theoretical and conceptual framework". Public and Municipal Finance, 7(2), 1-13. doi: 10.21511/pmf.07(2).2018.01

12.Klimuk V., \& Kochurko V., 2018. "Innovative development of countries: methodology". The Journal of V.N. Karazin Kharkiv National University Series "International Relations. Economics. Country Studies. Tourism", 8, 33-39 doi: 10.26565/2310-9513-2018-8-04

13.Koniaieva, Y. G., Babenko, V. A., 2019. "Determining priorities of scientific and technical cooperation between Ukraine, the EU and Chile in the field of non-conventional renewable energy sources". Acta Innovations, 32, 40-50. doi: https://doi.org/10.32933/Actalnnovation s.32.5

14. Mason, C. M., and Harrison, R. T., 2015. "Business Angel Investment Activity in the Financial Crisis: UK Evidence and Policy Implications." Environment and Planning C: Government and Policy, 33(1):43-60.

15.Memon, F. A., Saeed, S., \& Shaikh, A. (2018). Systematic Approach of Customer Relationship Management in Much Different Organization. IBT Journal of Business Studies, 14(2).

16.Naik, P. K., and Padhi, P., 2015. "Interaction of Institutional Investment Activity and Stock Market Volatility: Evidence from India." Asia-Pacific Journal of Management Research and Innovation, 11(3):219-229.

17.Kaminskyi, A., Nehrey, M., Komar, M., 2020, "Complex Risk Analysis of Investing in Agriculture ETFs". International Journal of Industrial Engineering \& Production Research, 31(4), 579-586.

18.Nepryadkina N.V., 2019. "Specifics and prospects of foreign trade development between Ukraine and the EU in agricultural sphere". The Journal of V.N. Karazin Kharkiv National University Series "International Relations. Economics. Country Studies. Tourism", 7, 60-65. 
19. Olena Palyvoda, Oksana Karpenko, Olena Bondarenko, Svitlana Bonyar and Andrea Bikfalvi, 2018. "Influence of network organizational structures on innovation activity of industrial enterprises." Problems and Perspectives in Management, 16(3), 174-188. doi:10.21511/ppm.16(3).2018.14

20.Přemysl Písař, 2019. "European SMEs' value management based on controlling, financial analysis and ratios - empirical study. Investment Management and Financial Innovations", 16(4), 277-289. doi:10.21511/imfi.16(4).2019.24

21.Syverson, C., 2019. "Macroeconomics and market power: context, implications, and open questions." Journal of Economic Perspectives, 33(3):23-43.

22.Yana Kolesnik, Olena Dobrovolska, Iryna Malyuta, Anna Petrova and Sergiy Shulyak, 2019. "The investment model of fixed assets renovation in the agricultural industry: case of Ukraine." Investment Management and Financial Innovations, 16(4), 229-239. doi:10.21511/imfi.16(4).2019.20 